\title{
Blockade of Stress-Induced But Not Cocaine-Induced Reinstatement by Infusion of Noradrenergic Antagonists into the Bed Nucleus of the Stria Terminalis or the Central Nucleus of the Amygdala
}

\author{
Francesco Leri, Joseph Flores, Demetra Rodaros, and Jane Stewart \\ Center for Studies in Behavioral Neurobiology, Concordia University, H3G-1M8, Montreal, Quebec, Canada
}

\begin{abstract}
Experiments in our laboratory have shown that central noradrenergic (NA) activation plays a major role in stress-induced reinstatement of drug seeking in rats. In the present experiments, we investigated the effects of blockade of $\beta$-NA adrenoceptors in the bed nucleus of the stria terminalis (BNST) and in the region of the central nucleus of the amygdala $(\mathrm{CeA})$ on footshock- and cocaine-induced reinstatement. Rats were trained to self-administer cocaine $(0.5 \mathrm{mg} / \mathrm{kg}$, i.v. $)$ for $9 \mathrm{~d}$ and, after a 5-7 d drug-free period, were given extinction sessions followed by a test for footshock stress-induced ( $15 \mathrm{~min}$ of intermittent footshock, $0.8 \mathrm{~mA})$ or cocaine-induced $(20 \mathrm{mg} / \mathrm{kg}$, i.p.) reinstatement. Before the test, different groups of rats were given bilateral infusions of one of four doses of a mixture of the $\beta_{1}$ - and $\beta_{2}$-receptor antagonists betaxolol and ICl-118,551 (ve-
\end{abstract}

hicle, $0.25,0.5$, and $1 \mathrm{nmol}$ of each compound in $0.5 \mu \mathrm{l}$ ) into either the BNST or CeA. We observed a dose-dependent reduction of stress-induced reinstatement after infusions into the BNST and a complete blockade of stress-induced reinstatement after infusions into the $\mathrm{CeA}$ at all doses tested. The same treatments did not block cocaine-induced reinstatement when given at either site. These data suggest that stress-induced NA activation in the BNST and in the region of the CeA is critical to relapse to drug seeking induced by stress but not to relapse induced by priming injections of cocaine, and we hypothesize that NA activity leads to activation of corticotropin-releasing factor neurons in these regions.

Key words: noradrenaline; stress; reinstatement; bed nucleus of the stria terminalis; central amygdala; cocaine
Studies in humans and laboratory animals have shown that relapse to drug seeking can be induced by re-exposure to small amounts of a drug (Ludwig et al., 1974; Stewart and de Wit, 1987; Jaffe et al., 1989), to drug-related stimuli (Childress et al., 1992; Tiffany and Carter, 1998; See et al., 1999), or to stressful events (Marlatt and Gordon, 1985; Childress et al., 1992; Shaham and Stewart, 1995; Shaham et al., 2000a).

In recent years, we have used an animal model of relapse, known as the reinstatement procedure (Stewart and de Wit, 1987), to study the neurobiological basis of stress-induced relapse. We have found that activation of central noradrenergic (NA) systems, known to play an important role in physiological and psychological responses to stress (Stanford, 1995; Bremner et al., 1996a,b; Southwick et al., 1999), is critically involved in stressinduced relapse. Systemic injections of agents that reduce cell firing and release of noradrenaline in the brain (Aghajanian and VanderMaelen, 1982; Carter, 1997), such as the $\alpha_{2}$-adrenoceptor agonists clonidine and lofexidine, block stress-induced reinstatement in cocaine-trained (Erb et al., 2000) and in heroin-trained (Shaham et al., 2000b) rats. In an attempt to identify which NA cell groups were involved in stress-induced relapse, bilateral infusions of clonidine or 2-(2,6-diethylphenylamino)-2-imidazoline $\mathrm{HCl}$ (a charged analog of clonidine with reduced lipophilic prop-

\footnotetext{
Received Jan. 16, 2002; revised April 5, 2002; accepted April 12, 2002.

This study was supported by the National Institute on Drug Abuse and by Fonds pour la Formation de Chercheurs et l'Aide à la Recherche, Quebec.

Correspondence should be addressed to Jane Stewart, Concordia University, Center for Studies in Behavioral Neurobiology, H-1013, 1455 de Maisonneuve Boulevard West, Montreal, Quebec, Canada, H3G 1M8. E-mail: stewart@csbn.concordia.ca. Copyright () 2002 Society for Neuroscience $\quad 0270-6474 / 02 / 225713-06 \$ 15.00 / 0$
}

erties) were made into the locus ceruleus, the origin of NA projections to various forebrain areas (Aston-Jones et al., 1995). The localized infusions, however, did not interfere with stressinduced reinstatement of heroin seeking (Shaham et al., 2000b), suggesting that the other major NA system, originating in the lateral tegmental nuclei, might be involved. These NA neurons project via the ventral NA bundle to forebrain structures, including the central amygdala $(\mathrm{CeA})$, the septum, and the bed nucleus of the stria terminalis (BNST) (Aston-Jones et al., 1995, 1999). Supporting this hypothesis, we have observed that selective 6-hydroxydopamine lesions to the ventral NA bundle significantly attenuated the reinstatement of heroin seeking induced by footshock stress (Shaham et al., 2000b). These findings, combined with findings showing the importance of corticotropin-releasing factor (CRF) activity in the BNST in stress-induced reinstatement (Erb and Stewart, 1999; Erb et al., 2001) and those showing that temporary inactivation of the BNST or CeA also blocks footshock-induced cocaine seeking (Shaham et al., 2000a), led us to study the role of NA activity in the BNST and CeA in stress-induced reinstatement.

To test the hypothesis that stress induces reinstatement of drugseeking by increasing noradrenaline release in the BNST and CeA, we investigated the effects of bilateral infusions of a mixture of $\beta_{1}$ and $\beta_{2}$-NA receptor antagonists (Aston-Jones et al., 1999) into either the BNST or into the region of the CeA on footshockinduced reinstatement of responding in cocaine-trained rats. In addition, to further explore the difference between the neurochemical systems involved in stress- and drug-induced relapse (Shaham et al., 2000a), we investigated the effects of such infusions on reinstatement induced by priming injections of cocaine. 


\section{MATERIALS AND METHODS}

\section{Subjects}

Male Long-Evans rats (375-450 gm; Charles River, Quebec, Canada) served as subjects. They were housed in a colony room on a reverse light-dark cycle (lights on at 8:00 P.M., lights off at 8:00 A.M.) and had access ad libitum to food and water at all times. The experimental procedures followed the guidelines of the Canadian Council on Animal Care and were approved by the Animal Care Committee, Concordia University, Quebec, Canada.

\section{Surgery}

Intravenous catheterization. Rats were prepared with intravenous silastic catheters (Dow Corning, Midland, MI) in the right jugular vein under sodium pentobarbital anesthesia $(65 \mathrm{mg} / \mathrm{kg}$, i.p.; MTC Pharmaceutical, Cambridge, Ontario, Canada). Rats were given atropine sulfate just before surgery $(0.6 \mathrm{mg} / \mathrm{ml} ; 0.3 \mathrm{ml} /$ rat, s.c.; MTC Pharmaceutical $)$ and penicillin B right after surgery (300,000 IU; $0.2 \mathrm{ml} /$ rat, i.m.; WyethAyerst, Montreal, Quebec, Canada). The catheter was secured to the vein with silk sutures and was passed subcutaneously to the top of the skull, where it exited into a connector (a modified 22 gauge cannula; Plastics One, Roanoke, VA) mounted to the skull with jeweler's screws and dental cement. A plastic blocker was placed over the opening of the connector during the recovery period and at all other times when the rats were not in a self-administration session. To prevent clogging, the catheters were flushed daily with saline and every third day with $0.1 \mathrm{ml}$ of a saline-heparin solution (15 IU/ml heparin; ICN Biochemicals, Cleveland, $\mathrm{OH}$ ).

Intracranial cannulation. During the same surgery session, guide cannulas (20 gauge; Plastics One) were implanted into each hemisphere. For the BNST group, the guide cannulas were aimed $2 \mathrm{~mm}$ above the ventrolateral region of the BNST. For the CeA group, the guide cannulas were aimed $2 \mathrm{~mm}$ above the CeA. Injectors extended $2 \mathrm{~mm}$ beyond the tip of the cannula to the infusion site. The stereotaxic coordinates used (relative to bregma and the skull surface) with the skull flat between bregma and lambda were as follows: BNST (arms positioned at $15^{\circ}$ ), anteroposterior $-0.6 \mathrm{~mm}$, midline $\pm 3.5 \mathrm{~mm}$, dorsoventral $-5.2 \mathrm{~mm}$; $\mathrm{CeA}$ (arms vertical), anteroposterior $-2.6 \mathrm{~mm}$, midline $\pm 4.6 \mathrm{~mm}$, dorsoventral $-6.2 \mathrm{~mm}$ (Paxinos and Watson, 1997). Animals were allowed at least $8 \mathrm{~d}$ to recover from surgery.

\section{Histology}

At the end of the experiment, animals were perfused transcardially under chloral hydrate $(400 \mathrm{mg} / \mathrm{kg})$ anesthesia with $10 \%$ formal hydratesaline solution. Brains were removed and fixed in a $10 \%$ formal saline and $25 \%$ sucrose solution for at least $24 \mathrm{hr}$ before sectioning. Brains were sectioned at $30 \mu \mathrm{m}$, and every other section through the BNST and the CeA was mounted and stained with cresyl violet. All data (i.e., selfadministration, extinction, and reinstatement) from individual subjects were discarded if the tips of the injectors fell beyond the boundaries of the intended site.

\section{Apparatus}

Eighteen Plexiglas operant chambers $(27 \times 27 \times 27 \mathrm{~cm}$; custom-made; Concordia University) were used in these experiments. Each chamber was enclosed in a larger $(87 \times 54 \times 43 \mathrm{~cm}$; custom-made; Concordia University) sound-attenuating plywood chamber. Each operant box had two levers located $10 \mathrm{~cm}$ above the floor of the box: one retractable and one stationary lever (Med Associates, Lafayette, IN). The retractable lever (active lever) was connected to an infusion pump (Razel Scientific Instruments, Stamford, CT) located outside the sound-insulating chamber for the delivery of drugs. Three centimeters above the active lever, there was a white-light stimulus that served as a discrete conditioned stimulus (CS). The stationary lever was located $10 \mathrm{~cm}$ from the active lever. Depression of this lever had no consequences (inactive lever), but all presses were recorded. Throughout the experiments, each session was started by the activation of a red house light and, $10 \mathrm{sec}$ later, by the entry of the retractable lever. The house light remained on for the duration of the session. Each self-administration chamber was fitted to deliver constant-current, intermittent, inescapable, electric footshock through a scrambler to the grid floor (Med Associates).

\section{Drugs}

Cocaine $\mathrm{HCl}$ was obtained from DBH Chemicals (Toronto, Ontario, Canada) and dissolved in physiological saline. Both betaxolol $\mathrm{HCl}$, the selective $\beta_{1}$-NA antagonist (Tocris, Ballwin, MO), and (+)-1-[2,3(dihydro-7-methyl-1H-inden-4-yl)oxy]-3-[(1-methylethyl)amino]-2-butanol (ICI-118,551) $\mathrm{HCl}$, the selective $\beta_{2}$-NA antagonist (Tocris) were dissolved in sterile distilled water. Three different concentrations of betaxolol and ICI-118,551 were used to prepare the mixture solutions $(0,0.25$, 0.5 , and $1 \mathrm{nmol}$ of each compound in $0.5 \mu \mathrm{l}$ ). This dose range was chosen in light of a previous study showing that $1 \mathrm{nmol}$ of a similar mixture of betaxolol and ICI-118,551 injected in the BNST was effective in blocking the development of aversion toward a place paired with opiate withdrawal (Aston-Jones et al., 1999).

\section{Procedure}

Self-administration. For the daily $3 \mathrm{hr}$ self-administration sessions, the rats were moved from their home cages to the operant chambers, and their connectors were attached to the inf usion lines. Each session started with the activation of a red house light, the entry of the retractable lever, and the illumination of the light CS for $30 \mathrm{sec}$. If the animal pressed on the active lever during this first $30 \mathrm{sec}$ presentation of the light CS, it received an infusion followed by termination of the light after $10 \mathrm{sec}$. Subsequent presses led to infusions of cocaine $(0.5 \mathrm{mg} / \mathrm{kg}$ per infusion) on a fixed-ratio 1 schedule of reinforcement. Drug was infused at a volume of $64 \mu \mathrm{l}$ over a $10 \mathrm{sec}$ period. During this period, the light CS was illuminated, thus serving as a CS paired with the drug infusion. Responses on the active lever made during the infusion were recorded but did not lead to additional infusions. The dose of cocaine was chosen on the basis of studies conducted in our laboratory indicating that rats trained with $0.5 \mathrm{mg} / \mathrm{kg}$ per inf usion display rapid and reliable acquisition of self-administration behavior. Drug concentration was adjusted for differences in body weight. Animals were allowed a maximum of 70 infusions per session. Training conditions were in place for $9 \mathrm{~d}$. At the end of training, animals were left undisturbed in the colony room for 5-7 $\mathrm{d}$ and subsequently were given extinction sessions and tests for reinstatement.

Extinction and tests for reinstatement. Throughout extinction and reinstatement testing, the animals were housed in the self-administration chambers and given access ad libitum to food and water, except during the actual experimental sessions. During extinction and reinstatement sessions, all of the conditions that were present during training were maintained, except that cocaine was never available.

All animals received 2 consecutive days of extinction training. On each day, they were given three 60 min extinction sessions with $30 \mathrm{~min}$ intervening periods, during which the active lever was withdrawn. After these $2 \mathrm{~d}$, most animals made $<15$ responses on the active lever in $1 \mathrm{hr}$. If that was not the case, individual rats received additional $1 \mathrm{hr}$ extinction sessions until the criterion of $<15$ responses/hr was met. When all animals reached the extinction criterion for that day, a test for reinstatement was given.

For the footshock reinstatement, the betaxolol and ICI-118,551 mixture was injected intracranially in a volume of $0.5 \mu \mathrm{l}$ over $1 \mathrm{~min}$ using a Harvard Apparatus pump 22 and a $1 \mu \mathrm{l}$ Harvard syringe (Harvard Apparatus, Montreal, Quebec, Canada). After these infusions, the animals were immediately returned to the testing chambers and, after a delay of $10 \mathrm{~min}$, were exposed to $15 \mathrm{~min}$ of intermittent footshock stress $(0.8 \mathrm{~mA} ; 0.5 \mathrm{sec}$ on; and a mean off period of $40 \mathrm{sec}$ ) (Shaham et al., 2000a). Immediately after the termination of footshock, the reinstatement session began with onset of the house light, the CS, and the introduction of the active lever. Test sessions were $3 \mathrm{hr}$ long.

For the cocaine reinstatement, the betaxolol and ICI-118,551 mixture was injected as described above, after which the animals received an intraperitoneal injection of $20 \mathrm{mg} / \mathrm{kg}$ cocaine or saline vehicle and were immediately returned to the testing chambers. After a period of $20 \mathrm{~min}$, the reinstatement session began with onset of the house light, the CS, and the introduction of the active lever.

For the BNST experiment, eight groups of animals were studied: four for shock-induced reinstatement and four for cocaine-induced reinstatement. Each group of animals received only one of the doses of the betaxolol/ICI-118,551 mixture or the vehicle.

For the CeA experiment, four groups of animals were studied. Animals from each group were tested twice after inf usions of the betaxolol/ ICI-118,551 mixture: once for footshock-induced and once for cocaineinduced reinstatement. Each animal was injected twice with the same dose of the mixture. Five days separated the two tests. During these days, the animals were left undisturbed in the operant chambers. This procedure differed from that used in the BNST experiment but allowed for 
A

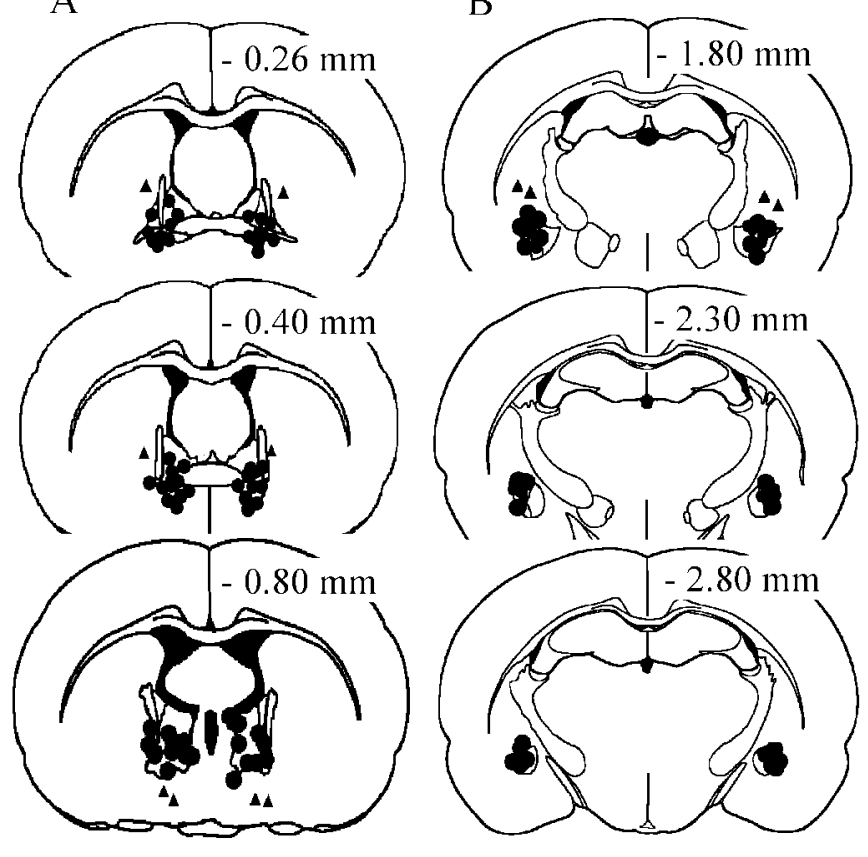

Figure 1. Distribution of infusion sites in the BNST $(A)$ and in the region of the $\mathrm{CeA}(B)$, plotted on drawings of coronal sections from the atlas of Paxinos and Watson (1997). The triangles in $A$ and $B$ represent inf usion sites outside the intended regions.

testing of the effect of the intracranial infusions in both reinstatement procedures in the same animal.

Effect of betaxolol/ICI-118,551 mixture on operant responding for sucrose pellets. To test for possible nonspecific effects of inf usions of the mixture into either the BNST or CeA region, two additional groups of eight rats were prepared with cannulas directed to either the BNST or CeA region. After $5 \mathrm{~d}$, these animals were trained to press the lever for sucrose pellets on a fixed-ratio 1 schedule of reinforcement for $10 \mathrm{~d}$ in $1 \mathrm{hr}$ sessions. On day 11 , the test day, all animals received an infusion of the highest dose of the mixture $(1 \mathrm{nmol}$ of each compound in $0.5 \mu \mathrm{l}) 20 \mathrm{~min}$ before insertion of the lever and the onset of the cue and house lights. Responses were recorded for $1 \mathrm{hr}$.

\section{RESULTS}

\section{Histology}

Histological analysis revealed that 73 of 80 rats had injector tips placed in the intended sites, 57 in the ventrolateral BNST (Fig. $1 A$ ), and 16 in the region of the CeA (Fig. $1 B$ ). In five rats with BNST cannulas, the injectors were either lateral or ventral (Fig. $1 A$, triangles). In two rats that had cannulas aimed at the amygdala but that received only vehicle infusions, injectors were dorsal to the $\mathrm{CeA}$ region (Fig. $1 \mathrm{~B}$, triangles). Of the animals with correct placements, 32 BNST animals were tested for footshock reinstatement (vehicle, $n=8 ; 0.25,0.5$, and $1 \mathrm{nmol}$ of betaxolol and ICI$118,551 / 0.5 \mu \mathrm{l}$, respectively, $n=7, n=8$, and $n=9$ ) and 25 animals were tested for cocaine reinstatement (vehicle, $n=6 ; 0.25,0.5$, and $1 \mathrm{nmol}$ of betaxolol and ICI-118,551/0.5 $\mu \mathrm{l}$, respectively, $n=7, n=$ 6 , and $n=6$ ). All of the CeA rats, as mentioned above, received two reinstatement tests, first with footshock and subsequently with cocaine (vehicle, $n=4 ; 0.25,0.5$, and $1 \mathrm{nmol}$ of betaxolol and ICI118,551/0.5 $\mu \mathrm{l}$, respectively, $n=4, n=4$, and $n=4$ ).

\section{Self-administration and extinction}

The animals acquired cocaine self-administration as indicated by an increase over days of responses emitted on the active lever (one-way repeated-measures ANOVA: $F_{(8,576)}=4.48 ; p<$

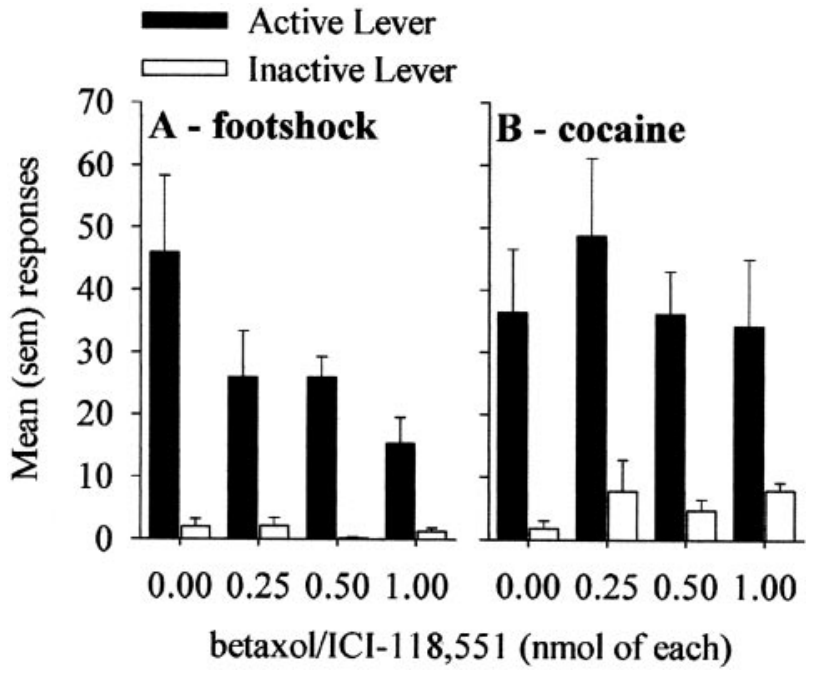

Figure 2. Effects of different doses of betaxol/ICI-118,551 mixture infused in the BNST on reinstatement of responding induced by footshock $(A)$ and on reinstatement induced by priming injections of cocaine $(B)$.

0.0001), an increase in the number of infusions obtained (one-way repeated-measures ANOVA: $\left.F_{(8,576)}=4.69 ; p<0.0001\right)$, and a progressive decrease in responding on the inactive lever (one-way repeated-measures ANOVA: $\left.F_{(8,576)}=27.7 ; p<0.0001\right)$. The mean numbers of infusions and the mean total responses (responses plus infusions) on the last $2 \mathrm{~d}$ of training were $34.7 \pm 1.5$, $38.7 \pm 1.3$ and $41.1 \pm 2.3,43.5 \pm 1.3$, respectively. During the first hour of extinction, when cocaine was no longer available, responding on the active lever increased, but over repeated sessions it decreased (one-way repeated-measures ANOVA: $F_{(5,360)}=$ 59.41; $p<0.0001)$; the mean number of responses on the last two $1 \mathrm{hr}$ sessions of extinction was below the criterion of 15 responses in $3 \mathrm{hr}(10.1 \pm 1.1$ and $6.9 \pm 1.1$, sessions 5 and 6 , respectively). Responding on the inactive lever did not change significantly during extinction.

\section{Reinstatement: betaxolol and ICI-118,551 in the BNST}

As shown in Figure $2 A$, the betaxolol/ICI-118,551 mixture infused into the BNST blocked shock-induced reinstatement in a dose-dependent manner (two-factor ANOVA on lever and dose; main effect of dose: $\left.F_{(3,56)}=2.98 ; p<0.05\right)$. This effect was not observed in five animals that received the infusions of betaxolol/ ICI-118,551 mixture outside the BNST (Fig. $1 \mathrm{~A}$, triangles; mean responses during reinstatement $=86.2 \pm 26.1$ ), thus suggesting an anatomic specificity of the intracranial infusions. In the group with correct placements, multiple comparisons (Fisher's test) confirmed that responding was significantly decreased at all doses compared with vehicle. Responding on the inactive lever was not affected by either footshock or the intracranial infusions.

In contrast to the effect on shock-induced reinstatement, none of the doses of betaxolol/ICI-118,551 infused into the BNST suppressed reinstatement induced by priming injections of cocaine (Fig. $2 B$ ). A two-factor ANOVA revealed only a significant main effect of lever $\left(F_{(1,42)}=26.6 ; p<0.0001\right)$, indicating that priming injections of cocaine reinstated responding selectively on the active lever. Post hoc tests revealed no significant effects of drug infusions at any dose. 


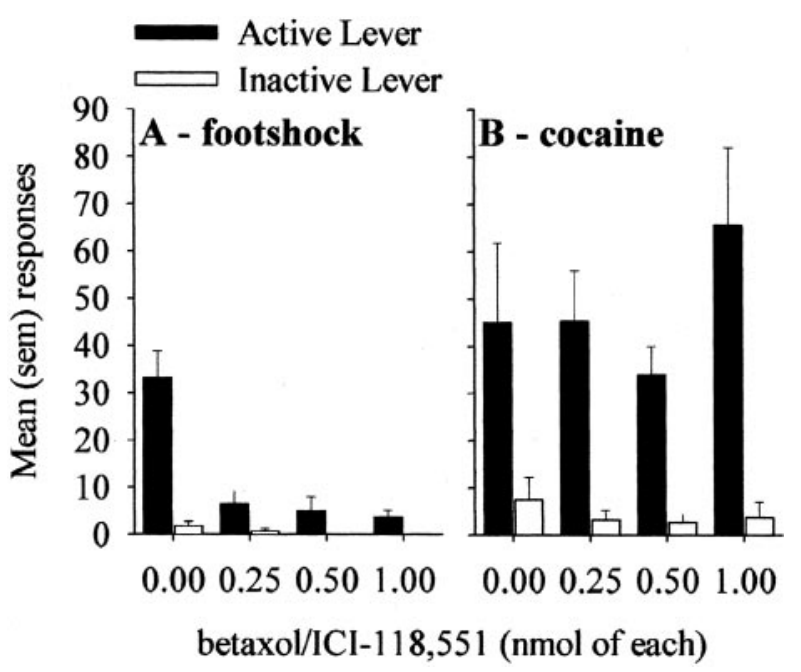

Figure 3. Effects of different doses of betaxol/ICI-118,551 mixture infused in the $\mathrm{CeA}$ on reinstatement of responding induced by footshock $(A)$ and on reinstatement induced by priming injections of cocaine $(B)$.

\section{Reinstatement: betaxolol and $\mathrm{ICI}-118,551$ in the CeA region}

Figure $3 A$ shows the effect of infusions of the betaxolol/ICI118,551 mixture in the region of the CeA on footshock-induced reinstatement. It can be seen that all doses of the mixture blocked reinstatement compared with vehicle, apparently in a doseindependent manner. There was a significant dose by lever interaction (two-factor ANOVA: $F_{(3,12)}=16.7 ; p<0.001$ ), and multiple comparisons confirmed that footshock reinstated responding selectively on the active lever only in the animals that received vehicle infusions in the $\mathrm{CeA}$.

Interestingly, as illustrated in Figure $3 B$, the same intra-CeA infusions, given to the same animals, had no effect on cocaineinduced reinstatement. A two-factor ANOVA revealed only a significant main effect of lever $\left(F_{(1,12)}=31.8 ; p<0.0001\right)$, indicating that the priming injections of cocaine reinstated responding selectively on the active lever. Post hoc tests revealed no significant effects of drug infusions at any dose.

\section{Effect of betaxolol and ICl-118,551 on operant responding for sucrose pellets}

The mean number of sucrose pellets obtained per session over the last $6 \mathrm{~d}$ of training for the BNST and CeA region groups was $71.6 \pm 2.4$ and $58.3 \pm 9.2$, respectively. The mean number of pellets obtained after the infusions of the mixture into the BNST and the CeA region was $67.7 \pm 21$ and $83.6 \pm 18.2$, respectively. No significant differences were found between performance during the last days of training and on the test day.

\section{DISCUSSION}

In the present experiments, it was found that antagonism of $\beta$-NA receptors in both the BNST and the CeA region blocked footshock-induced reinstatement of cocaine seeking. The effect of the mixture of the $\beta_{1}$ - and $\beta_{2}$-NA antagonists was dose-dependent in the BNST, whereas in the region of the CeA, it blocked stress-induced reinstatement at all doses tested. Infusions of the $\beta$-receptor antagonists in either the BNST or the CeA region had no effect on the reinstatement induced by priming injections of cocaine at any of the doses tested. This latter finding, combined with the lack of effect of the same intracranial infusions on lever pressing for sucrose pellets, shows clearly that the betaxolol/ICI118,551 mixture did not block shock-induced reinstatement because of nonspecific effects. In the case of the BNST, the effect of the antagonists was shown to be site specific in that infusions made ventral or dorsal to the BNST were ineffective. In the case of the amygdala, infusions were directed at the CeA, but it is not possible to exclude the possibility that they invaded the basolateral nucleus of the amygdala, known to receive NA projections and to be sensitive to $\beta$-adrenergic antagonists. Note, however, that $\beta$-adrenergic antagonists infused into the basolateral nucleus of the amygdala interfere with fear conditioning and the consolidation of fear memories (McGaugh et al., 1993; Quirarte et al., 1997), whereas in our studies, we are evaluating the effects of such compounds on the response to an acute presentation of an unconditioned stressor.

The finding that NA activity in both the BNST and $\mathrm{CeA}$ region is important in stress-induced reinstatement is consistent with our previous findings that partial 6-hydroxydopamine lesions of the ventral NA bundle projecting to these regions attenuate footshock-induced reinstatement (Shaham et al., 2000b). Various acute stressors have been shown to induce release of noradrenaline in the BNST (Pacak et al., 1995a). Within the CeA, noradrenaline has been found to be released in response to both acute (Galvez et al., 1996; Quirarte et al., 1998; Hatfield et al., 1999) and chronic (Iimori et al., 1982; Ida et al., 1985; Pacak et al., 1993) stressors. In addition, we have found that the footshock used in our studies of reinstatement increases noradrenaline release in the ventral lateral BNST (R. Gandhi, H. Rajabi, D. Rodaros, J. Stewart, unpublished observations), as well as in the amygdala and medial prefrontal cortex (Erb et al., 2000). Furthermore, these effects are blocked by systemic doses of clonidine that block stress-induced reinstatement of both cocaine and heroin seeking (Erb et al., 2000; Shaham et al., 2000a).

Our present finding that blockade of NA activity in either the $\mathrm{CeA}$ region or BNST suppresses reinstatement induced by footshock might be accounted for by any of several consequences that such NA blockade has on projection regions. For example, the $\mathrm{CeA}$ proper projects to several brainstem nuclei involved in autonomic responses, and damage to the $\mathrm{CeA}$ interferes with the expression of unconditioned and conditioned fear responses, such as freezing (for review, see LeDoux, 2000). However, because the response to footshock in the context of reinstatement is to engage actively in lever-pressing behavior, it is unlikely that the suppression of such fear responses would account for the effect of NA blockade in the CeA region. The BNST projects to the hypothalamic paraventricular nucleus involved in control of pituitaryadrenal function (Herman et al., 1994; Makino et al., 1994, 1995; Pacak et al., 1995a,b; Nail-Boucherie et al., 1998; Zhu et al., 2001), but we have shown that stress-induced activation of the hypothalamic-pituitary-adrenal axis is not directly involved in stress-induced reinstatement of drug-seeking (for review, see Shaham et al., 2000a). The BNST also projects to lower brainstem nuclei involved in aggressive attack (Shaikh et al., 1986) and has been shown to be critically involved in species-typical behaviors, such as maternal behavior (Komisaruk et al., 2000). One projection that may be relevant to the role of the BNST in the activation of motivated behavior is that to the ventral tegmental area (Morrell et al., 1984). Stimulation of the BNST activates mesolimbic dopaminergic cells in the ventral tegmental area (Marcangione et al., 2000; Georges and Aston-Jones, 2001), and it was shown recently that rats will lever press for electrical stimulation in this brain region (Marcangione et al., 2001). 
The BNST also contains cells that are immunoreactive to CRF (Swanson et al., 1983), and there is substantial anatomic evidence indicating that noradrenaline and CRF interact in this region. Hornby and Piekut (1989) identified a population of CRF cell bodies in the ventrolateral BNST surrounded by dopamine $\beta$-hydroxylase-immunoreactive processes. A double-label immunocytochemical study confirmed that NA terminals form synapses with dendrites of CRF neurons in the ventrolateral BNST (Phelix et al., 1994). The CeA also sends a CRF-containing projection to the BNST (Sakanaka et al., 1986), which we have shown plays a role in stress-induced reinstatement of cocaine seeking. Inf usions of the CRF antagonist D-Phe CRF 12-41 into the ventrolateral BNST block stress-induced reinstatement, whereas similar infusions into the amygdala are without effect (Erb and Stewart, 1999). We found, however, that interruption of the projection from the CeA to the BNST in one hemisphere combined with infusion of D-Phe CRF 12-41 into the BNST in the other hemisphere attenuated stress-induced reinstatement (Erb et al., 2001). These findings, combined with those from the present study showing a functional role for noradrenaline in both the amygdala and BNST, strongly suggest that noradrenaline could interact with CRF-containing neurons in both regions to bring about stress-induced reinstatement of cocaine seeking. We have approached the nature of the interaction between noradrenaline and CRF in the BNST by using in vivo microdialysis to measure noradrenaline release in the BNST in response to footshock after intracerebroventricular infusions of the CRF antagonist D-Phe CRF 12-41. These intracerebroventricular inf usions, which block shock-induced reinstatement (Shaham et al., 1997; Erb et al., 1998), did not interfere with shock-induced release of norepinephrine (NE) (our unpublished observations), suggesting that the effects of CRF in the BNST occur subsequently to the action of NE in this region (Erb and Stewart, 1999). Indeed, at least at the level of CRF cells in the mediobasal hypothalamus, NE has been shown to induce the release of CRF through activation of $\beta$-NA receptors (Tsagarakis et al., 1988; Joanny et al., 1989; Widmaier et al., 1989; Orliaguet et al., 1995). Thus, together with the results of the present experiment, we suggest that a potential mechanism mediating the effects of footshock on reinstatement of drug seeking is via the release of noradrenaline in the amygdala and BNST, which, through action at $\beta$-NA receptors, activates CRF-containing cells in both regions. Some of these CRFcontaining neurons project from the CeA to the BNST, and others are intrinsic to the BNST itself. This idea, of course, does not rule out other actions of noradrenaline in these regions, but it does suggest that the critical event for the initiation of reinstatement induced by stress is the release of CRF in the BNST.

The finding that the behavioral effect of $\beta$-NA antagonists was dose-dependent in the BNST but not in the $\mathrm{CeA}$ region suggests that the $\mathrm{CeA}$ modulates the activity of the BNST in response to stressful stimulation. Although it is known that there are noradrenergic projections to both the amygdala and BNST and that there are CRF-containing cells in both regions, as discussed above, the amygdala sends a dense CRF projection to the BNST. It is possible, therefore, that even low doses of NA antagonists infused into the $\mathrm{CeA}$ region could have had profound effects on reinstatement, because they could have prevented the release of CRF in the BNST.

It is important to note that blocking $\beta$ receptors in the BNST and in the $\mathrm{CeA}$ region did not prevent the reinstatement induced by priming injections of cocaine. We have data from microdialysis studies in the BNST indicating that both a cocaine injection and exposure to the stressor used in these experiments elevate noradrenaline levels in the BNST (data not shown). The present data clearly indicate that such increases in noradrenaline are not critical for reinstatement induced by priming injections of cocaine. Furthermore, other studies have shown that reinstatement induced by priming injections of cocaine is largely dependent on dopaminergic mechanisms (for review, see Shaham et al., 2000a; Stewart, 2000). Together, these studies suggest that the neural mechanisms mediating drug-induced reinstatement are dissociable from the neural systems mediating stress-induced reinstatement.

\section{REFERENCES}

Aghajanian GK, VanderMaelen CP (1982) Alpha 2-adrenoceptormediated hyperpolarization of locus coeruleus neurons: intracellular studies in vivo. Science 215:1394-1396.

Aston-Jones G, Shipley MT, Grzanna R (1995) The locus coeruleus, A5 and A7 noradrenergic cell groups. In: The rat nervous system (Paxinos G, ed), pp 183-213. San Diego: Academic.

Aston-Jones G, Delfs JM, Druhan J, Zhu Y (1999) The bed nucleus of the stria terminalis: a target site for noradrenergic actions in opiate withdrawal. Ann NY Acad Sci 877:486-498.

Bremner JD, Krystal JH, Southwick SM, Charney DS (1996a) Noradrenergic mechanisms in stress and anxiety. I. Preclinical studies. Synapse 23:28-38.

Bremner JD, Krystal JH, Southwick SM, Charney DS (1996b) Noradrenergic mechanisms in stress and anxiety. II. Clinical studies. Synapse 23:39-51.

Carter AJ (1997) Hippocampal noradrenaline release in awake, freely moving rats is regulated by alpha- 2 adrenoceptors but not by adenosine receptors. J Pharmacol Exp Ther 281:648-654.

Childress AR, Ehrman R, Rohsenow DJ, Robbins SJ, O'Brien CP (1992) Classically conditioned factors in drug dependence. In: Substance abuse: a comprehensive textbook (Lowinson JH, Ruiz P, Millman RB, eds), pp 56-69. Baltimore: Williams and Wilkins.

Erb S, Stewart J (1999) A role for the bed nucleus of the stria terminalis, but not the amygdala, in the effects of corticotropin-releasing factor on stressinduced reinstatement of cocaine seeking. J Neurosci 19:RC35:1-6.

Erb S, Shaham Y, Stewart J (1998) The role of corticotropin-releasing factor and corticosterone in stress- and cocaine-induced relapse to cocaine seeking in rats. J Neurosci 18:5529-5536.

Erb S, Hitchcott PK, Rajabi H, Mueller D, Shaham Y, Stewart J (2000) Alpha-2 adrenergic receptor agonists block stress-induced reinstatement of cocaine seeking. Neuropsychopharmacology 23:138-150.

Erb S, Salmaso N, Rodaros D, Stewart J (2001) A role for the CRFcontaining pathway from central nucleus of the amygdala to bed nucleus of the stria terminalis in stress-induced relapse to cocaine seeking in rats. Psychopharmacology 158:360-365.

Galvez R, Mesches MH, McGaugh JL (1996) Norepinephrine release in the amygdala in response to footshock stimulation. Neurobiol Learn Mem 66:253-257.

Georges F, Aston-Jones G (2001) Potent regulation of midbrain dopamine neurons by the bed nucleus of the stria terminalis. J Neurosci 21:RC160:1-6.

Hatfield T, Spanis C, McGaugh JL (1999) Response of amygdalar norepinephrine to footshock and GABAergic drugs using in vivo microdialysis and HPLC. Brain Res 835:340-345.

Herman JP, Cullinan WE, Watson SJ (1994) Involvement of the bed nucleus of the stria terminalis in tonic regulation of paraventricular hypothalamic CRH and AVP mRNA expression. J Neuroendocrinol 6:433-442.

Hornby PJ, Piekut DT (1989) Opiocortin and catecholamine input to CRF-immunoreactive neurons in rat forebrain. Peptides 10:1139-1146.

Ida Y, Tanaka M, Tsuda A, Tsujimaru S, Nagasaki N (1985) Attenuating effect of diazepam on stress-induced increases in noradrenaline turnover in specific brain regions of rats: antagonism by Ro 15-1788. Life Sci 37:2491-2498.

Iimori K, Tanaka M, Kohno Y, Ida Y, Nakagawa R, Hoaki Y, Tsuda A, Nagasaki N (1982) Psychological stress enhances noradrenaline turnover in specific brain regions in rats. Pharmacol Biochem Behav 16:637-640.

Jaffe JH, Cascella NG, Kumor KM, Sherer MA (1989) Cocaineinduced cocaine craving. Psychopharmacology 97:59-64.

Joanny P, Steinberg J, Zamora AJ, Conte-Devolx B, Millet Y, Oliver C (1989) Corticotropin-releasing factor release from in vitro superfused and incubated rat hypothalamus: effect of potassium, norepinephrine, and dopamine. Peptides 10:903-911.

Komisaruk BR, Rosenblatt JS, Barona ML, Chinapen S, Nissanov J, O'Bannon RT, Johnson BM, Del Cerro MC (2000) Combined c-fos and 14C-2-deoxyglucose method to differentiate site-specific excitation from disinhibition: analysis of maternal behavior in the rat. Brain Res 859:262-272. 
LeDoux JE (2000) Emotion circuits in the brain. Annu Rev Neurosci 23:155-184.

Ludwig AM, Wikler A, Stark LH (1974) The first drink: psychobiological aspects of craving. Arch Gen Psychiatry 30:539-547.

Makino S, Gold PW, Schulkin J (1994) Effects of corticosterone on CRH mRNA and content in the bed nucleus of the stria terminalis: comparison with the effects in the central nucleus of the amygdala and the paraventricular nucleus of the hypothalamus. Brain Res 657:141-149.

Makino S, Schulkin J, Smith MA, Pacak K, Palkovits M, Gold PW (1995) Regulation of corticotropin-releasing hormone receptor messenger ribonucleic acid in the rat brain and pituitary by glucocorticoids and stress. Endocrinology 136:4517-4525.

Marcangione C, Stewart J, Rompre PP (2000) Electrical stimulation of the bed nucleus of the stria terminalis produces opposite effects on midbrain dopamine and non-dopamine cell firing. Soc Neurosci Abstr 26:477.27.

Marcangione C, Stewart J, Rompre PP (2001) Localization of rewardrelevant sites within the bed nucleus of the stria terminalis: a moveable electrode mapping study. Soc Neurosci Abstr 27:421.13.

Marlatt GA, Gordon JR (1985) Relapse prevention: maintenance strategies in the treatment of addictive behavior. New York: Guilford.

McGaugh JL, Introini-Collison IB, Cahill LF, Castellano C, Dalmaz C, Parent MB, Williams CL (1993) Neuromodulatory systems and memory storage: role of the amygdala. Behav Brain Res 58:81-90.

Morrell JI, Schwanzel-Fukuda M, Fahrbach SE, Pfaff DW (1984) Axonal projections and peptide content of steroid hormone concentrating neurons. Peptides [Suppl] 5:227-239.

Nail-Boucherie K, Garcia R, Jaffard R (1998) Influences of the bed nucleus of the stria terminalis and of the paraventricular nucleus of the hypothalamus on the excitability of hippocampal-lateral septal synapses in mice. Neurosci Lett 246:112-116.

Orliaguet G, Melik P, Lenoir V, Duval P, Kerdelhue B (1995) Norepinephrine but not epinephrine stimulates the release of corticotropinreleasing factor from in vitro superfused rat hypothalamus. J Neurosci Res 42:236-241.

Pacak K, Palkovits M, Kvetnansky R, Fukuhara K, Armando I, Kopin IJ, Goldstein DS (1993) Effects of single or repeated immobilization on release of norepinephrine and its metabolites in the central nucleus of the amygdala in conscious rats. Neuroendocrinology 57:626-633.

Pacak K, McCarty R, Palkovits M, Kopin IJ, Goldstein DS (1995a) Effects of immobilization on in vivo release of norepinephrine in the bed nucleus of the stria terminalis in conscious rats. Brain Res 688:242-246.

Pacak K, Palkovits M, Kopin IJ, Goldstein DS (1995b) Stress-induced norepinephrine release in the hypothalamic paraventricular nucleus and pituitary-adrenocortical and sympathoadrenal activity: in vivo microdialysis studies. Front Neuroendocrinol 16:89-150.

Paxinos G, Watson C (1997) The rat brain in stereotaxic coordinates. San Diego: Academic.

Phelix CF, Liposits Z, Paull WK (1994) Catecholamine-CRF synaptic interaction in a septal bed nucleus: afferents of neurons in the bed nucleus of the stria terminalis. Brain Res Bull 33:109-119.

Quirarte GL, Roozendaal B, McGaugh JL (1997) Glucocorticoid enhancement of memory storage involves noradrenergic activation in the basolateral amygdala. Proc Natl Acad Sci USA 94:14048-14053.

Quirarte GL, Galvez R, Roozendaal B, McGaugh JL (1998) Norepi- nephrine release in the amygdala in response to footshock and opioid peptidergic drugs. Brain Res 808:134-140.

Sakanaka M, Shibasaki T, Lederis K (1986) Distribution and efferent projections of corticotropin-releasing factor-like immunoreactivity in the rat amygdaloid complex. Brain Res 382:213-238.

See RE, Grimm JW, Kruzich PJ, Rustay N (1999) The importance of a compound stimulus in conditioned drug-seeking behavior following one week of extinction from self-administered cocaine in rats. Drug Alcohol Depend 57:41-49.

Shaham Y, Stewart J (1995) Stress reinstates heroin-seeking in drug-free animals: an effect mimicking heroin, not withdrawal. Psychopharmacology 119:334-341.

Shaham Y, Funk D, Erb S, Brown TJ, Walker CD, Stewart J (1997) Corticotropin-releasing factor, but not corticosterone, is involved in stress-induced relapse to heroin-seeking in rats. $J$ Neurosci 17:2605-2614.

Shaham Y, Erb S, Stewart J (2000a) Stress-induced relapse to heroin and cocaine seeking in rats: a review. Brain Res Brain Res Rev 33:13-33.

Shaham Y, Highfield D, Delfs J, Leung S, Stewart J (2000b) Clonidine blocks stress-induced reinstatement of heroin seeking in rats: an effect independent of locus coeruleus noradrenergic neurons. Eur J Neurosci 12:292-302.

Shaikh MB, Brutus M, Siegel HE, Siegel A (1986) Regulation of feline aggression by the bed nucleus of stria terminalis. Brain Res Bull 16:179-182.

Southwick SM, Bremner JD, Rasmusson A, Morgan CA, Arnsten A, Charney DS (1999) Role of norepinephrine in the pathophysiology and treatment of posttraumatic stress disorder. Biol Psychiatry 46:1192-1204.

Stanford SC (1995) Central noradrenergic neurones and stress. Pharmacol Ther 68:297-242.

Stewart J (2000) Pathways to relapse: the neurobiology of drug- and stress-induced relapse to drug-taking. J Psychiatry Neurosci 25:125-136.

Stewart J, de Wit H (1987) Reinstatement of drug-taking behavior as a method of assessing incentive motivational properties of drugs. In: Methods of assessing the reinforcing properties of abused drugs (Bozarth MA, ed), pp 211-227. New York: Springer.

Swanson LW, Sawchenko PE, Rivier J, Vale WW (1983) Organization of ovine corticotropin-releasing factor immunoreactive cells and fibers in the rat brain: an immunohistochemical study. Neuroendocrinology 36:165-186.

Tiffany ST, Carter BL (1998) Is craving the source of compulsive drug use? J Psychopharmacol 12:23-30.

Tsagarakis S, Holly JM, Rees LH, Besser GM, Grossman A (1988) Acetylcholine and norepinephrine stimulate the release of corticotropin-releasing factor-41 from the rat hypothalamus in vitro. Endocrinology 123:1962-1969.

Widmaier EP, Lim AT, Vale W (1989) Secretion of corticotropinreleasing factor from cultured rat hypothalamic cells: effects of catecholamines. Endocrinology 124:583-590.

Zhu W, Umegaki H, Suzuki Y, Miura H, Iguchi A (2001) Involvement of the bed nucleus of the stria terminalis in hippocampal cholinergic system-mediated activation of the hypothalamo-pituitaryadrenocortical axis in rats. Brain Res 916:101-106. 